\title{
A COMMON FRAMEWORK FOR UNDERSTANDING \\ Non-State Organizations?
}

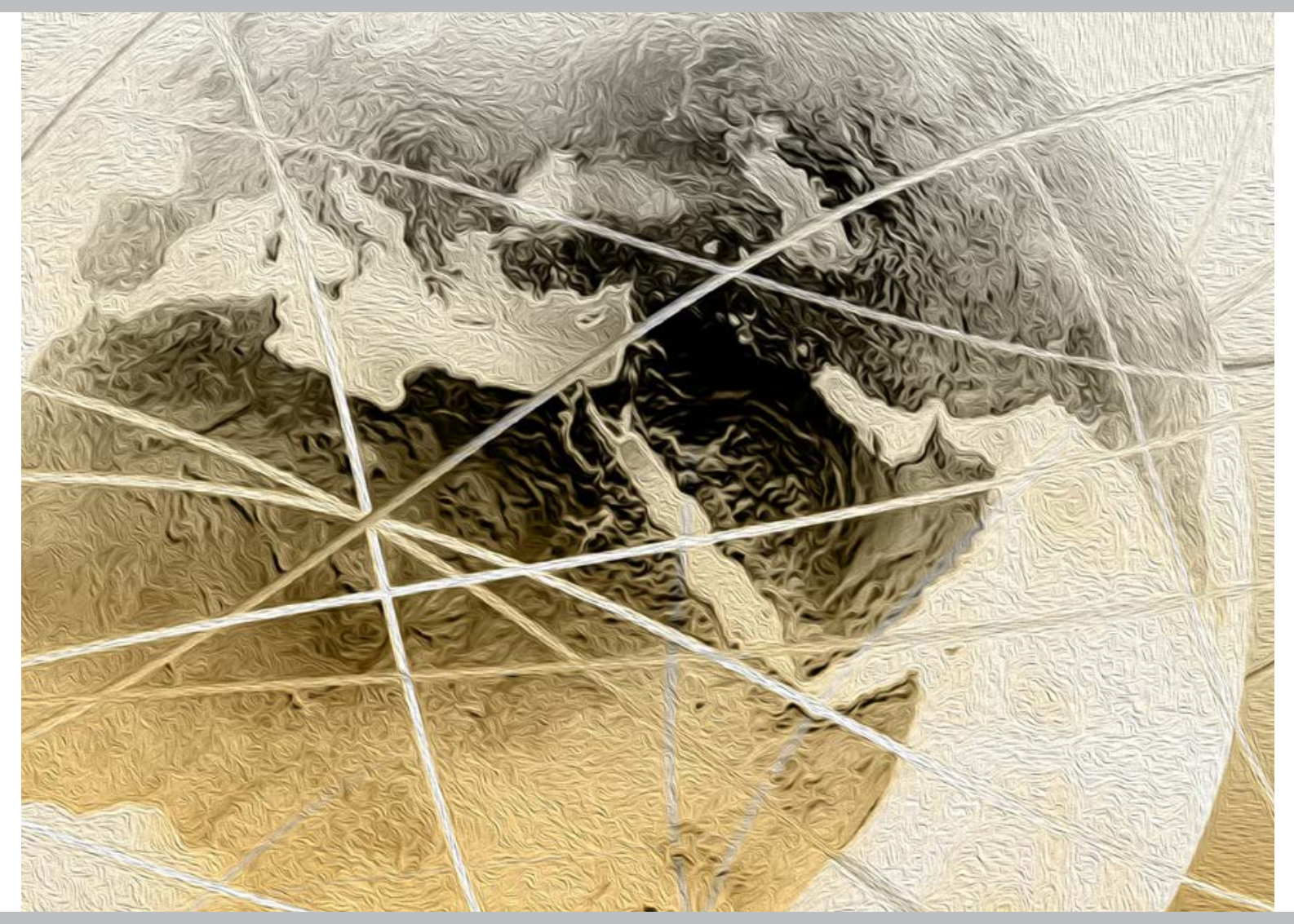

a One Earth Future

Research Report by

Lindsay L. Heger, Danielle Jung, Sarah Stroup, and Wendy Wong

$2 \times$ one earth 


\section{A Common Framework FOR UNDERSTANDING \\ Non-State Organizations?}

\section{Authors:}

Lindsay L. Heger

Associate Director of Research

One Earth Future Foundation

Danielle Jung

Assistant Professor

Emory University

Sarah Stroup

Assistant Professor

Middlebury College

Wendy Wong

Associate Professor

University of Toronto 


\section{A COMMON FrameWork FOR UNDERSTANDing Non-STATE ORganizations? ${ }^{1}$}

The prevalence of non-state actors in political discourse and policy implementation is a striking new feature of the contemporary global political arena. Evolving policymaking paradigms now routinely incorporate the preferences, know-how, and abilities of these actors in many areas including peacebuilding, international disaster response, human rights, regional and global trade, and even diplomatic exchange. The recent literature on the importance of non-state actors for global political outcomes is sizeable, ${ }^{2}$ with several prominent volumes advancing theoretical frameworks to help us better theorize and situate such actors in International Relations (IR) and policymaking. We take the importance of such actors as a given, and seek to build bridges between scholars and practitioners working on/in non-state organizations.

Of the many ways to divide up these actors, one potentially fruitful avenue is to focus on those nonstate actors that have some identifiable aspects of formal organization-"non-state organizations" (NSOs). ${ }^{3}$ The idea of NSOs is still a broad one, a category that includes a number of important players in global politics but seemingly frustrates attempts at generalization. This paper serves as an introduction to conceptualizations of NSOs and, in particular, non-governmental organizations (NGOs), multinational corporations (MNCs), intergovernmental organizations (IGOs), and dark networks. We focus on those groups here as they constitute a sizeable portion of contemporary NSO activity and we anticipate a useful synthesis from a narrower approach.

For individual groups, there are many potential explanations for both why an actor might choose a particular organizational structure as well as the effects of that choice on the work of the organization. ${ }^{4}$ Generally, we observe a number of theories imported into the study of NSOs, yielding a wide range of exciting works. Yet there are few scholarly comparisons across different actors or rigorous tests of competing explanations. For practitioners, siloed managerial practices similarly stymie organizational development. The potential for NGO, private sector, and civic leaders to learn about cross-sector efficiency and assessment protocols is vast and not fully tapped.

We have two goals for this framing paper. First, we hope to identify a common set of concerns that all NSOs face (if possible). We hope to highlight the challenges faced by scholars and practitioners in understanding NSOs, and to bring to relief themes and concepts that might run across more than one of these types of actors. We begin with the basic choice of organizational structure. Corporations, terrorists, charities, and intergovernmental organizations must constantly revisit the question of how to organize themselves. Through a comparative analysis of organizational structure, we hope to advance our knowledge of both individual types of NSOs as well as the category as a whole.

Second, our goal is to bring together practitioners and policy-oriented perspectives with scholarly research. Research on NSOs is fragmented, and the quality of the conversation between practitioners and scholars can be weak at best - a real detriment for the study of NSOs. From the outside, the transparency of decision making processes can be quite limited, leading to incomplete and possibly

2 | A COMmon Framework For Understanding Non-State Organizations 
misleading inference. Meanwhile, if the scholarly analysis of organizational design does not translate into clear, practical, useful advice for those involved in creating organizational structures, practitioners may be increasingly reluctant to open up to scholarly analysis. We know of a number of NGOs suffering from this sort of fatigue - tired of being put under the microscope without getting useful insights in return.

Modestly, we aim to shrink the distance between the two communities in two ways. First, we hope to forge a path toward creating a community of interested entrepreneurial researchers and practitioners who find value in the groups' collective insights and contributions. Second, we hope that this sort of discussion will generate a common language and set of metrics that we can all use to communicate better these insights and advance our individual understandings of how best to conceptualize and/or participate in important policy arenas.

Below we review our understanding of how and why NSOs make organizational choices. Additionally, the effects of organizational structure have broad-reaching implications for other kinds of questions, which we discuss below. The discussion below is broken into three sections: choice of organizational structure, effect of structure, and assessment of structure. In each section we outline our thoughts on the issue and provide guiding questions to motivate participants' contributions.

\section{Choosing and Comparing Organizational Structures}

We begin with a discussion of the varieties of organizational structures across NSOs and why NSOs choose particular organizational forms. In other words, what explanations exist for structure as a dependent variable? We also discuss a number of dimensions along which we can make comparisons among different types of organizations.

Theoretically, the menu of organizational forms includes hierarchies, networks, and markets (Powell 1990), a typology that emphasizes both variation in formality and lines of authority. While markets are "flat" and lack regularized authority, hierarchies are characterized by clear "vertical" lines of authority and obligation. In this typology, networks are "in-between," though there are a number of conceptions that challenge this neat set of models. ${ }^{5}$

Given the plethora of organizations that are "non-state," we have a rich pool of varied organizational structures. ${ }^{6}$ How do groups as diverse as MNCs, terrorist groups, IGOs, and NGOs choose their structures? Are particular types of actors more likely to exhibit particular organizational characteristics, or do we see similar variation in organizational type within each category? Are there advantages to certain types of structures for a type of actor, or does organizational choice vary with other external or internal factors? 
As a first exercise in bridging the different fields in which we each work, we present the "landscape" of existing analyses of organizational structure (Table 1 below). In each of the cells of the table, we offer an example of current claims about the relationship between a particular factor and organizational structure. These examples come from both the academic and practitioner literatures, and we have focused more on concrete causal claims over broader theoretical perspectives. This is most definitely a work in progress, and we do not pretend to offer an exhaustive review of NSOs. ${ }^{7}$ Still, this exercise helps us individually situate ourselves while advancing a collective conversation about the state of our knowledge.

The rows identify factors that affect organizational structure across a range of NSOs. For example, the role of donors in shaping the organizational structures of IGOs and NGOs has been explored using principal-agent models and resource dependency theory. ${ }^{8}$ Normatively, many practitioners question how to establish alternate accountability mechanisms for a wider range of stakeholders beyond donors. ${ }^{9}$ There are a number of additional factors that could be included as determinants of organizational structure, including the role of leadership, the effects of an organization's history (path dependence), the opportunities created by new technologies, and the interaction of agency and structure. ${ }^{10}$

The columns identify the four types of NSOs included here. As experts in a particular field, we tend to silo ourselves into the study of specific actor types. Yet comparisons among types of NSOs are growing. Prakash and Gugerty (2010) liken advocacy NGOs to firms. Heger, Jung, and Wong (2012) draw on the ideas of transaction costs and functional differentiation to explain the relative efficacy of violence for more centralized violent NSOs. Inspired by the argument that there are many "varieties of capitalism" from which MNCs originate, Stroup (2012) argues that international NGOs similarly are shaped by their national environments. These pieces suggest different constellations of effect, internal structures, and external environment and, taken together, paint a more complete picture of what shapes NSO activities.

We recognize that there are other ways to divide the complex category of NSOs beyond the "actor type" method used in the table columns. We could also differentiate among NSOs based on whether they are illicit (dark) or licit, self-interested (primarily MNCs) versus other-interested, religious (a crosscutting category) or secular, or we could consider their geographic scope (regional versus global). We could also divide up the field based on issue area-many analyses of global governance tackle the issue of NSOs by examining the "multi-stakeholder systems" that operate in particular issue areas (e.g., global health, climate change, natural resource extraction). ${ }^{11}$ Insofar as these alternate dimensions are relevant to a discussion of the organization of NSOs, they likely deserve attention.

We view organizational attributes as a dimension on which all types of NSOs co-vary and, thus, as a useful starting point. And we anticipate a number of interesting exchanges. For example, the illicit nature of dark networks limits the formal nature of their organization as well as the transparency of their processes - the Weather Underground never filed IRS Form 990. But if these "illicit authorities" (Hall and Biersteker 2002) are providing goods and services the state is unwilling or unable to provide, they need some basic organizational capacity and coordination to do so effectively. Are

4 | A COMmon Framework for Understanding Non-State Organizations? 
dark networks as a type more networked/less hierarchical than other types of NSOs because they operate beyond state and global regulation? It is this sort of question that we hope is provoked by the organizing exercise of the table.

\section{A. Comparing Organizations}

The question of variations in organizational structure across NSOs is an important one. However, beyond establishing a typology and range of organizations such as that in Table 1, we also seek a discussion around dimensions of organizational structure that are consequential for understanding how an organization relates to its peers (NGOs in relation to other NGOs, for example) and other actors in global politics. To that end, we identify seven features relevant to NSO structural outcomes.

- Agenda-setting: How does the organization decide to take up a new issue or create a new product? Who are the veto players within the organization?

- Implementation: Who is tasked with putting organizational plans into action? How independent are these players from the agenda-setters?

- Porousness: How fixed are the boundaries of the organization? Are individual units given autonomy to pursue more or less robust relationships with other actors (e.g., collaboration on research and development [R\&D] among aviation companies, coordination among humanitarian relief providers through the United Nations' Office for the Coordination of Humanitarian Affairs [OCHA])?

- Branding: Has the organization developed and protected a particular brand? How did this brand emerge, and how is the brand promoted and defended in relation to other actors?

- Scale: How does the size of the organization affect coordination problems, economies of scale, and the legitimacy of the organization across a range of contexts?

- Resource acquisition and allocation: What are the sources of organizational support? How numerous and diverse are those supporters? For corporations, who are the buyers of the MNC product? How does the organization engage in the task of resource acquisition and subsequent allocation among its component parts?

- Personnel: Who works for the organization? What are the mechanisms for recruitment and retention? What qualifications must individuals possess to work for the organization, 
and how have those standards evolved over time? Are organizations in a single field (e.g., human rights activism) adopting uniform professional standards, or is there substantial differentiation, and why?

Two important caveats are necessary. First, these dimensions of organizations are not static, either for individual actors or for organizational fields. One central question for discussion is whether, over time, different types of NSOs are converging along some of these dimensions. For example, the language of branding has been taken up far beyond the field of corporations; NGOs like Oxfam and IGOs like UNICEF work hard to identify and protect their brands. Does branding mean the same thing for different types of NSOs? To what extent are all of the intra-organizational dimensions identified above characteristic of all organizations, and to what extent do some "belong" to certain types of NSOs because they are more prominent concerns?

A second caveat is that we need to unpack the formal organizational structure from the informal practice within the organization. In a widely cited essay from 1997, John Meyer and Brian Rowan characterized formal organizational structure as "myth and ceremony" often decoupled from the actual work of the organization. We are deeply interested in the range and type of disconnect between formal and informal practice across the span of NSOs, as well as explanations for why this disconnect is created or persists. Because some of the more interesting organizational insights happen outside of the organizational flow charts, terms of reference, and other formal mechanisms, we recognize it is also important to identify each of these dimensions, where possible, at the informal level.

\section{STRUCTURE AND OUTCOMES}

We are also interested in structure as an independent variable. Ultimately, as scholars and practitioners, we care about organizational structure because we think it has consequences for organizational practices. Different structures affect the efficiency, effectiveness, prominence, or even the very survival of a non-state actor. A few examples from the different types of actors are illustrative:

- Efficiency: Centralization of decision-making may minimize the administrative costs of the organization and allow for more specific targeting of resources across the organization in a way that maximizes the bang for each buck. Interestingly, efficiency concerns seem to be prominent across the range of NSOs, though for different reasons. Multinational corporations can maximize profits by minimizing expenses, while NGOs and IGOs are able to deflect heightened scrutiny from their funders by providing evidence of the efficient use of funds ${ }^{12}$ or by taking advantage of organizational forms that allow for economies of scale.

- Effectiveness: Centralization within terrorist and rebel groups has proven to shorten the length of conflict, but also increases the damage inflicted by attacks. Groups that are centralized tend to do so along functional dimensions (i.e., functional differentiation). In turn, differentiation produces specialization and, for terrorist groups, the result is on average more lethal attacks.

6 | A COMmon Framework for Understanding Non-State Organizations? 
- Salience: The United Nations Development Programme is highly decentralized and engaged in multiple networks. According to Craig Murphy, this makes it a creative learning organization (unlike most IGO bureaucracies), but the organization is also poorly funded and a low priority for the major bilateral donors (Murphy 2006: 18-22). UNDP's more networked form may make it a better incubator for new development ideas, but perhaps at the cost of the sort of prominence that might make it able to translate those ideas into practice..$^{13}$ Similarly, international criminal networks face a challenge with the concealment-coordination dilemma (Kenney 2009), since they need coordination to achieve their goals, but too much organizational structure leads to detection by authorities and works against remaining concealed.

- Survival: Networks may be highly effective in the short term, but without the creation of a centralized structure and formal organization, they may disappear as issue areas from the global agenda or as networks. Famously, the International Campaign to Ban Landmines had no office or bank account when it won the Nobel Peace Prize in 1997, but as of 2012 it had offices in Geneva and London, a staff of eleven, and a budget of \$3.6 million (all of which are shared with the Cluster Munition Coalition). ${ }^{14}$

Structural choices may have unintended effects, which we find to be one of the most compelling aspects of studying organizations. For example, structural changes undertaken to please external donors (the creation of an office for monitoring and evaluation, for example) may have the unintended or unwanted effect of changing organizational practice in another area (changing the type of services offered or level of transparency). Structural choices have effects on the perceived effectiveness and efficacy of an organization. These effects may attenuate over time.

\section{Measuring and Assessing Organizational Structure}

The micro-level task of assessing organizational structures is a challenging one, and has enormous effects at the macro level when we think of comparing different types of actors and organizations. For scholars of different types of NSOs, we seek to compare notes about creating indicators of organizational structure. For practitioners, the utility of assessment for internal growth and development is still not fully embraced and where it exists the mechanisms are not entirely consistent with social scientific principles.

Organizational structure may be stickier than practitioners like to think in the way that organizational ethos endures, branding matters, and changing organizational structures can often be a struggle. Conversely, organizational structures may be more ephemeral than scholars would like, with informal arrangements dominating and even overshadowing more easily documentable formal structures and shifts in leadership resulting in widespread organizational change. 
Scholars and practitioners may also value different kinds of evaluation. Social science values systematic, generalizable measures that may not be possible given the nature of some NSOs and the paucity of available (or realistically attainable) data. Academics and policymakers also prioritize accountability and building institutions to maximize such concerns. Practitioners may have an altogether different orientation. Whereas on-the-ground assessments may improve delivery of services, they may not improve the overall efficiency of an NSO. Similarly, things that "work" for dark networks may prove very costly, or they may degrade communications between different parts of a group in order to maximize concealment. Using the same types of measurements, over a long period of time, may not make sense for many practitioners as problems shift and priorities respond to these shifts. Tracking GDP per capita for "development" may seem antiquated in 2014 in light of the multiplicity of ways development is affected, but it provides the longitudinal consistency academics crave.

One conversation that may be unavoidable here is the challenge of defining "effectiveness" or "success" for different NSOs. This conversation is an important one, and insofar as we are interested in the question above about the effects of organizational structure, we cannot avoid the subject. Still, our collective comparative advantage may be in brainstorming ways of tracking changes within these organizations rather than tackling weighty questions like "how should we define development" or "how do we know if an audience to terror attacks has been terrorized?"

\section{Conclusion}

One of our central goals is to build bridges across a number of different, sometimes disconnected, groups. We wish to challenge the self-categorization and isolating differentiation that curtail much contemporary research on NSOs. Intergovernmental organizations, non-governmental organizations, multinational corporations, and violent groups all operate alongside states and are all important players in global politics, but we understand little about the characteristics that unite them as a category. The organizational dimension is one issue that all NSOs face, though we leave it up for discussion whether the question of organization is a unifying one for the range of NSOs under examination.

Additionally, we seek to bring together practitioners and scholars interested in the same sorts of questions but perhaps coming at them from different angles and with different end goals. For those in the field who develop and implement programs and seek to enhance their returns and efficiency, we hope that more conversations toward a common language and series of metrics will allow opportunities for cross-fertilization. Sharing insights between practitioner and academic communities is one way this can be achieved. We see real potential in the exchange of practical lessons across different types of NSOs. We also expect that a fertile exchange between researchers and practitioners will help hone the conversation toward issues and topics that are relevant to real-world advances in understanding and interacting in our increasingly complex global arena. 
Table 1 Organizational Traits and NSO TyPeS

\begin{tabular}{|c|c|c|c|c|}
\hline FACTORS & NGOs & IGOs & MNCs & DARK NETWORKS \\
\hline $\begin{array}{l}\text { Level of } \\
\text { centralization }\end{array}$ & $\begin{array}{l}\text { Campaigns } \\
\text { with centralized } \\
\text { agenda-setting } \\
\text { and decentralized } \\
\text { implementation are } \\
\text { more effective (Wong } \\
\text { 2012) }\end{array}$ & $\begin{array}{l}\text { States choose } \\
\text { informal IGOs } \\
\text { (like the G20) over } \\
\text { centralization when } \\
\text { uncertainty and } \\
\text { sovereignty costs are } \\
\text { high (Vabulas and } \\
\text { Snidal 2013) }\end{array}$ & $\begin{array}{l}\text { Efficiency } \\
\text { goals encourage } \\
\text { centralization the } \\
\text { need for local } \\
\text { tailoring discourages } \\
\text { it (Bartlett and } \\
\text { Ghoshal 1998) }\end{array}$ & $\begin{array}{l}\text { Al Qaeda's core } \\
\text { group is more lethal } \\
\text { but its planned } \\
\text { attacks are less } \\
\text { successful than } \\
\text { peripheral movement } \\
\text { groups (Helfstein and } \\
\text { Wright 2011) }\end{array}$ \\
\hline $\begin{array}{l}\text { Donor } \\
\text { preference }\end{array}$ & $\begin{array}{l}\text { Bilateral donors } \\
\text { pressure NGOs to } \\
\text { professionalize and } \\
\text { centralize (Roberts, } \\
\text { Jones, and Frohling } \\
\text { 2005); NGO } \\
\text { effectiveness suffers } \\
\text { as a result (Cooley } \\
\text { and Ron 2002) }\end{array}$ & $\begin{array}{l}\text { Donor countries to } \\
\text { the International } \\
\text { Monetary Fund } \\
\text { (IMF) are } \\
\text { overrepresented in } \\
\text { IMF governance, } \\
\text { despite } 2010 \text { reforms } \\
\text { (Wade 2011; Leech } \\
\text { and Leech 2013) }\end{array}$ & $\begin{array}{l}\text { MNC subsidiaries } \\
\text { that are more } \\
\text { dependent on } \\
\text { outsiders are less } \\
\text { likely to follow local } \\
\text { practices in human } \\
\text { resource management } \\
\text { (Rosenzweig and } \\
\text { Nohria 1994) }\end{array}$ & $\begin{array}{l}\text { To assure external } \\
\text { sponsors of their } \\
\text { importance, rebel } \\
\text { groups in western } \\
\text { Uganda engaged } \\
\text { in dramatic attacks } \\
\text { against civilians } \\
\text { (Hovil and Werker } \\
\text { 2005) }\end{array}$ \\
\hline $\begin{array}{l}\text { Legitimacy } \\
\text { concerns } \\
\text { (Dimaggio } \\
\text { and Powell } \\
\text { 1983) }\end{array}$ & $\begin{array}{l}\text { ActionAid } \\
\text { restructured to claim } \\
\text { legitimacy as a global } \\
\text { NGO (Jayawickrama } \\
\text { and Ebrahim 2013) }\end{array}$ & $\begin{array}{l}\text { The EU has created } \\
\text { European citizenship } \\
\text { and a parliament } \\
\text { to boost legitimacy } \\
\text { (McNamara 2010) }\end{array}$ & $\begin{array}{l}\text { European firms } \\
\text { favored liberalization } \\
\text { of service trade even } \\
\text { when it threatened } \\
\text { their monopolies } \\
\text { (Woll 2008) }\end{array}$ & \\
\hline $\begin{array}{l}\text { Transaction } \\
\text { costs }\end{array}$ & & & $\begin{array}{l}\text { Firms internalize } \\
\text { production to limit } \\
\text { transaction costs } \\
\text { (Williamson 1981) }\end{array}$ & $\begin{array}{l}\text { Terrorist leaders } \\
\text { face significant } \\
\text { inefficiencies due to } \\
\text { skimming along the } \\
\text { management chain } \\
\text { (Shapiro and Siegel } \\
\text { 2007) }\end{array}$ \\
\hline $\begin{array}{l}\text { Bureaucratic } \\
\text { politics }\end{array}$ & $\begin{array}{l}\text { NGOs protecting } \\
\text { white rhinos face a } \\
\text { trade-off between } \\
\text { long-term security } \\
\text { and conservation } \\
\text { (Avant 2004) }\end{array}$ & $\begin{array}{l}\text { Concern over the } \\
\text { UN's legitimacy } \\
\text { led the Secretary- } \\
\text { General to ignore } \\
\text { signs of genocide in } \\
\text { Rwanda (Barnett and } \\
\text { Finnemore 2004) }\end{array}$ & $\begin{array}{l}\text { Excessive monitoring } \\
\text { within MNCs } \\
\text { reduces flexibility } \\
\text { and information flow } \\
\text { (O’Donnell 2000) }\end{array}$ & $\begin{array}{l}\text { Terrorist } \\
\text { organizations face } \\
\text { the same bureaucratic } \\
\text { constraints as } \\
\text { firms (Shapiro } \\
\text { 2013); insurgent } \\
\text { organizations use } \\
\text { their compensation } \\
\text { structure as a tool to } \\
\text { solve management } \\
\text { problems (Bahney et } \\
\text { al. 2013) }\end{array}$ \\
\hline
\end{tabular}




\begin{tabular}{|c|c|c|c|c|}
\hline \multicolumn{5}{|c|}{ TABle 1 Continued } \\
\hline FACTORS & NGOs & IGOs & MNCs & DARK NETWORKS \\
\hline $\begin{array}{l}\text { Functional } \\
\text { concerns }\end{array}$ & $\begin{array}{l}\text { The need to quickly } \\
\text { and reliably collect } \\
\text { and disseminate } \\
\text { information on } \\
\text { rights abuses led to } \\
\text { the centralization of } \\
\text { research at Amnesty } \\
\text { Int'l (Clark 2001; } \\
\text { Winston 2001) }\end{array}$ & $\begin{array}{l}\text { The need for } \\
\text { an enforcement } \\
\text { mechanism at UN } \\
\text { led to creation of } \\
\text { Security Council } \\
\text { (Bosco 2009); the } \\
\text { need for expertise } \\
\text { allows bureaucrats at } \\
\text { IGOs to participate in } \\
\text { institutional reform } \\
\text { (Johnson 2013) }\end{array}$ & $\begin{array}{l}\text { The need to produce/ } \\
\text { market many } \\
\text { related products } \\
\text { led to "M-form" } \\
\text { corporation (Chandler } \\
\text { 1962) }\end{array}$ & $\begin{array}{l}\text { The need to track } \\
\text { individual operatives } \\
\text { leads to substantial } \\
\text { record-keeping } \\
\text { among otherwise } \\
\text { covert terrorist } \\
\text { organizations } \\
\text { (Shapiro and Siegel } \\
\text { 2012) }\end{array}$ \\
\hline $\begin{array}{l}\text { Variations } \\
\text { in state } \\
\text { regulation }\end{array}$ & $\begin{array}{l}\text { Different charity } \\
\text { laws facilitate fund- } \\
\text { raising in the US and } \\
\text { advocacy in France } \\
\text { (Stroup 2012); } \\
\text { state regulatory } \\
\text { rules incentivize } \\
\text { trusts, nonprofits, } \\
\text { and unincorporated } \\
\text { associations } \\
\text { differently (Hopkins } \\
\text { and Blazek 2008) }\end{array}$ & & $\begin{array}{l}\text { Market protection } \\
\text { in developing states } \\
\text { leads MNCs to create } \\
\text { local subsidiaries; } \\
\text { differential tax rates } \\
\text { lead to transfer } \\
\text { pricing }\end{array}$ & $\begin{array}{l}\text { Counterterrorism } \\
\text { alters transaction } \\
\text { costs and the } \\
\text { structure of terrorist } \\
\text { organizations } \\
\text { (Helfstein 2009); } \\
\text { failed states are } \\
\text { havens for armed } \\
\text { groups (Takeyh and } \\
\text { Gvosdev 2002) }\end{array}$ \\
\hline Globalization & $\begin{array}{l}\text { Growing size/ } \\
\text { scale of relief and } \\
\text { development sector } \\
\text { leads to restructuring } \\
\text { of NGOs (Lindenberg } \\
\text { and Bryant 2001) }\end{array}$ & $\begin{array}{l}\text { Growth in } \\
\text { transborder issues } \\
\text { leads to expansion in } \\
\text { number and scope of } \\
\text { IGOs (Keohane and } \\
\text { Nye } 1977 \text { ) }\end{array}$ & $\begin{array}{l}\text { Complexity of global } \\
\text { production has led to } \\
\text { "alliance capitalism," } \\
\text { blurring boundaries } \\
\text { among firms } \\
\text { (Dunning 2002) }\end{array}$ & $\begin{array}{l}\text { For armed NSOs, } \\
\text { globalization enables } \\
\text { better communication } \\
\text { among network } \\
\text { members and their } \\
\text { partners/allies } \\
\text { (Shultz, Farah, and } \\
\text { Lochard 2004) }\end{array}$ \\
\hline
\end{tabular}




\section{Works Cited}

Avant, Deborah. 2004. "Conserving Nature in the State of Nature: The Politics of INGO Policy Implementation." Review of International Studies 30(3): 361-382. doi:10.1017/s0260210504006114

Avant, Deborah, Martha Finnemore, and Susan Sell, eds. 2010. Who Governs the Globe? New York: Cambridge University Press. doi:10.1017/cbo9780511845369

Bahney, Benjamin, Radha Iyengar, Patrick Johnston, Danielle Jung, Jacob Shapiro, and Howard Shatz. 2013. "Insurgent Compensation: Evidence from Iraq." American Economic Review: Papers and Proceedings 103(3): 518-522. doi:10.1257/aer.103.3.518

Barnett, Michael, and Liv Coleman. 2005. "Designing Police: Interpol and the Study of Change in International Organizations." International Studies Quarterly 49(4): 593-620. doi:10.1111/j.14682478.2005.00380.x

Barnett, Michael, and Martha Finnemore. 2004. Rules for the World: International Organizations in Global Politics. Ithaca: Cornell University Press.

Bartlett, Christopher A., and Sumantra Ghoshal. 1998. Managing across Borders: The Transnational Solution. Edition 2. Boston: Harvard Business School Press.

Bosco, David L. 2009. Five to Rule Them All: The United Nations Security Council and the Making of the Modern World. New York: Oxford University Press.

Brown, L. David, Alnoor Ebrahim, and Srilatha Batliwala. 2012. "Governing International Advocacy NGOs." World Development 40(6): 1098-1108. doi:10.1016/j.worlddev.2011.11.006

Chandler, Alfred Dupont. 1962. Strategy and Structure. Vol. 4. Cambridge, MA: MIT Press.

Clark, Ann Marie. 2001. Diplomacy of Conscience: Amnesty International and Changing Human Rights Norms. Princeton: Princeton University Press. doi:10.1515/9781400824229

Cooley, Alexander. 2008. Logics of Hierarchy: The Organization of Empires, States, and Military Occupations. Ithaca: Cornell University Press.

Cooley,Alexander, andJamesRon.2002."TheNGOScramble:OrganizationalInsecurityand thePoliticalEconomy of Transnational Action.” International Security 27(1): 5-39. doi:10.1162/016228802320231217

DiMaggio, Paul J., and Walter W. Powell. 1983. "The iron cage revisited: Institutional isomorphism and collective rationality in organizational fields." American sociological review 48 (2): 147-160. doi: $10.2307 / 2095101$

Drezner, Daniel W. 2007. All Politics Is Global: Explaining International Regulatory Regimes. Princeton: Princeton University Press. doi:10.1515/9781400828630

Dunning, John H. 2002. Alliance Capitalism and Global Business. New York: Routledge.

Ebrahim, Alnoor. 2003. “Accountability in Practice: Mechanisms for NGOs.” World Development 31(5): 813829. doi:10.1016/s0305-750x(03)00014-7

Green, Jessica. 2013. Rethinking Private Authority: Agents and Entrepreneurs in Global Environmental Governance. Princeton: Princeton University Press. doi:10.1515/9781400848669

Hall, Rodney Bruce, and Thomas J. Biersteker, eds. 2002. The Emergence of Private Authority in Global Governance. Cambridge: Cambridge University Press. doi:10.1017/cbo9780511491238 
Heger, Lindsay, Danielle Jung, and Wendy H. Wong. 2012. “Organizing for Resistance: How Group Structure Impacts the Character of Violence." Terrorism and Political Violence 24(5): 743-768. doi:10.1080/0 $\underline{9546553.2011 .642908}$

Helfstein, Scott. 2009. "Governance of Terror: New Institutionalism and the Evolution of Terrorist Organizations." Public Administration Review 69(4): 727-739. doi:10.1111/j.1540-6210.2009.02020.x

Helfstein, Scott, and Dominick Wright. 2011. "Covert or Convenient? Evolution of Terror Attack Networks." Journal of Conflict Resolution 55(5): 785-813. doi:10.1177/0022002710393919

Hopkins, Bruce R., and Jody Blazek. 2008. Private Foundations: Tax Law and Compliance. Hoboken, NJ: John Wiley and Sons.

Hovil, Lucy, and Eric Werker. 2005. "Portrait of a Failed Rebellion: An Account of Rational, Sub-Optimal Violence in Western Uganda." Rationality and Society 17(1): 5-34. doi:10.1177/1043463105051775

Jayawickrama, Sherine, and Alnoor Ebrahim. 2013. "Building and Governing a Democratic Federation: The ActionAid International Story.” Occasional Paper, Harvard Hauser Center for Nonprofit Organizations.

Johnson, Tana. 2013. "Looking beyond States: Openings for International Bureaucrats to Enter the Institutional Design Process." Review of International Organizations 8(4): 499-519. doi:10.1007/s11558-013$\underline{9166-0}$

Kenney, Michael. 2009. "Turning to the 'Dark Side': Coordination, Exchange, and Learning in Criminal Networks.” In Networked Politics: Agency, Power, and Governance, ed. Miles Kahler. Ithaca: Cornell University Press.

Keohane, Robert, and Joseph S. Nye. 1977. Power and Interdependence: World Politics in Transition. New York: Little, Brown.

Lake, David, and Wendy Wong. 2009. "The Politics of Networks: Interests, Power, and Human Rights Norms." In Networked Politics: Agency, Power, and Governance, ed. Miles Kahler. Ithaca: Cornell University Press. doi:10.2139/ssrn.1004199

Leech, Dennis, and Robert Leech. 2013. "A New Analysis of a Priori Voting Power in the IMF." In Power, Voting, and Voting Power: 30 Years After, ed. Manfred J. Holler and Hannu Nurmi, 389-410. New York: Springer. doi:10.1007/978-3-642-35929-3 21

Lewis, Orion A., and Sven Steinmo. 2012. "How Institutions Evolve: Evolutionary Theory and Institutional Change." Polity 44(3): 314-339. doi: 10.1057/pol.2012.10

Lindenberg, Marc, and Coralie Bryant. 2001. Going Global: Transforming Relief and Development NGOs. Bloomfield, CT: Kumarian Press.

McNamara, Kathleen. 2010. "Constructing Authority in the European Union." In Who Governs the Globe?, ed. Deborah Avant, Martha Finnemore, and Susan Sell, 153-179. New York: Cambridge University Press. doi:10.1017/cbo9780511845369.007

Meyer, John W., and Brian Rowan. 1977. "Institutionalized Organizations: Formal Structure as Myth and Ceremony." American Journal of Sociology 83(2): 340-363. doi: 10.1086/226550

Murphy, Craig. 2006. The United Nations Development Programme. Cambridge: Cambridge University Press. doi:10.1017/cbo9780511618000

Neumann, Iver, and Ole Jacob Sending. 2010. Governing the Global Polity: Practice, Mentality, Rationality. Ann Arbor: University of Michigan Press.

Nielson, Daniel, and Michael Tierney. 2003. "Delegation to International Organizations: Agency Theory and World Bank Environmental Reform.” International Organization 57(2): 241-276. doi:10.1017/ $\underline{\mathrm{s} 0020818303572010}$ 
O'Donnell, Sharon Watson. 2000. "Managing Foreign Subsidiaries: Agents of Headquarters, or an Interdependent Network?" Strategic Management Journal 21(5): 525-548. doi:10.1002/(sici)1097-

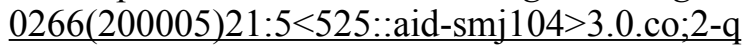

Powell, Walter W.1990. "Neither Market nor Hierarchy.” Research in Organizational Behavior. Vol. 12: $295-$ 336.

Prakash, Aseem, and Mary Kay Gugerty, eds. 2010. Advocacy Organizations and Collective Action. Cambridge: Cambridge University Press. doi:10.1017/cbo9780511762635

Roberts, Susan, John Paul Jones III, and Oliver Frohling. 2005. "NGOs and the Globalization of Managerialism: A Research Framework." World Development 33: 1845-1864. doi:10.1016/j.worlddev.2005.07.004

Rosenzweig, Philip M., and Nitin Nohria. 1994. "Influences on Human Resource Management Practices in Multinational Corporations." Journal of International Business Studies 25(2): 229-251. doi:10.1057/ palgrave.jibs.8490199

Shapiro, Jacob N., and David A. Siegel. 2007. "Underfunding in Terrorist Organizations." International Studies Quarterly 51(2): 405-429. doi:10.1111/j.1468-2478.2007.00457.x

Shapiro, Jacob N., and David A. Siegel. 2012. "Moral Hazard, Discipline, and the Management of Terrorist Organizations." World Politics 64(1): 39-78. doi:10.1017/s0043887111000293

Shapiro, Jacob. N. 2013. The Terrorist's Dilemma:Managing Violent Covert Organizations. Princeton: Princeton University Press. doi:10.1515/9781400848645

Shultz, Richard H., Douglas Farah, and Itamara V. Lochard. 2004. Armed Groups: A Tier-One Security Priority. No. INSS-OP-57. Institute for National Security Studies, US Air Force Academy.

Stroup, Sarah S. 2012. Borders among Activists. Ithaca: Cornell University Press.

Takeyh, Ray, and Nikolas Gvosdev. 2002. "Do Terrorist Networks Need a Home?” Washington Quarterly 25(3): 97-108. doi:10.1162/01636600260046262

Triantaphyllis, Christina and Matthew Forti. "Impact, Not Overhead, Is What Counts," Stanford Social Innovation Review. November 13, 2013. Accessed April 21, 2014. http://www.ssireview.org/blog/ entry/impact_not_overhead_is_what_counts) blog.

Vabulas, Felicity, and Duncan Snidal. 2013. “Organization without Delegation: Informal Intergovernmental Organizations (IIGOs) and the Spectrum of Intergovernmental Arrangements." Review of International Organizations 8(2): 1-28. doi:10.1007/s11558-012-9161-x

Wade, Robert H. 2011. "Emerging World Order? From Multipolarity to Multilateralism in the G20, the World Bank, and the IMF." Politics and Society 39(3): 347-378.doi:10.1177/0032329211415503

Wasik, John F. "How to Choose a Charity Wisely." The New York Times, November 7, 2013. Accessed April 21, 2014. http://www.nytimes.com/2013/11/08/giving/how-to-choose-a-charity-wisely.html?_r=0.

Watts, Duncan J. 2004. Six Degrees: The Science of a Connected Age. New York: W.W. Norton \& Company.

Williamson, Oliver E. 1981. "The Economics of Organization: the Transaction Cost Approach." American journal of sociology. 87 (3): 548-577. doi:10.1086/227496

Winston, Morton E. 2001. "Assessing the Effectiveness of International Human Rights NGOs: Amnesty International." In NGOs and Human Rights: Promise and Performance, ed. Claude E. Welch Jr. Philadelphia: University of Pennsylvania Press. 
Woll, Cornelia. 2008. Firm Interests: How Governments Shape Business Lobbying on Global Trade. Ithaca: Cornell University Press.

Wong, Wendy H. 2012. Internal Affairs: How the Structure of NGOs Transforms Human Rights. Ithaca: Cornell University Press.

Yanacopulos, Helen. 2005. "The Strategies That Bind: NGO Coalitions and Their Influence." Global Networks 5(1): 93-110. doi:10.1111/j.1471-0374.2005.00109.x

\section{Notes}

1. The following paper was circulated as the framing paper for the Non-State Organizations Workshop hosted by the University of Toronto and co-sponsored by the One Earth Future Foundation and the Middlebury and Monterey Consortium. It was intended to provide a common context for all participants and to spark debate about what the authors view as a series of questions relevant to both non-state organization practitioners and scholarly research.

2. For two very different examples, see Neumann and Sending (2010) and Avant, Finnemore, and Sell (2012).

3. This conceptualization thereby excludes other forms that non-state actors in IR might take, including social movements and networks of organizations that are not formal groups (e.g., the G20).

4. More formally, structure can be both consequence (dependent variable) and cause (independent variable) in understandings of an organization's practices.

5. See Watts (2004); Lake and Wong (2009).

6. Even states vary in their organizational form (Cooley 2008).

7. Indeed, we invite comments on factors or approaches we have missed.

8. Nielson and Tierney (2003); Barnett and Coleman (2005); Green (2013); Yanacopulos (2005).

9. Ebrahim (2003); Brown, Ebrahim, and Batliwala (2012).

10. Lewis and Steinmo (2012).

11. See Avant, Finnemore, and Sell (2010) for a compilation of examples.

12. Of course, efficiency may be a goal related to the means of an organization rather than the end. The charity rating watchdogs in the United States have come under fire for prioritizing efficiency metrics over effectiveness metrics. The reforms have had mixed results, as efficiency is an easier concept to define and measure. See "How to Choose a Charity Wisely," New York Times, November 7, 2013 (http://www.nytimes.com/2013/11/08/giving/ how-to-choose-a-charity-wisely.html); Christina Triantaphyllis and Matthew Forti, "Impact, Not Overhead, Is What Counts," Stanford Social Innovation Review (http://www.ssireview.org/blog/entry/impact_not_overhead_is_what_ counts) blog, November 13, 2013.

13. Drezner (2007) cautions against confusing visibility with influence. We are not convinced that only publicly visible non-state organizations are effective, but public attention may be one possible route to policy influence.

14. http://www.icbl.org/index.php/icbl/About-Us/Reports (accessed November 14, 2013). 
The One Earth Future Foundation was founded in 2007 with the goal of supporting research and practice in the area of peace and governance. OEF believes that a world beyond war can be achieved by the development of new and effective systems of cooperation, coordination, and decision making. We believe that business and civil society have important roles to play in filling governance gaps in partnership with states. When state, business, and civil society coordinate their efforts, they can achieve effective, equitable solutions to global problems.

As an operating foundation, we engage in research and practice that supports our overall mission. Research materials from OEF envision improved governance structures and policy options, analyze and document the performance of existing governance institutions, and provide intellectual support to the field operations of our implementation projects. Our active field projects apply our research outputs to existing governance challenges, particularly those causing threats to peace and security.

The OEF research report series is intended to promote interesting and thought-provoking ideas relevant to key questions of peace and global governance.

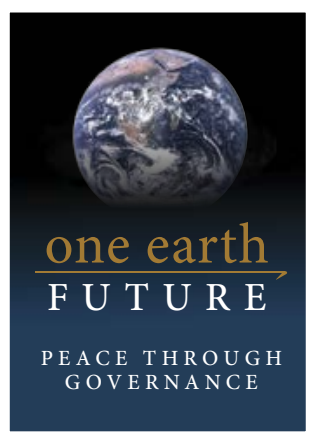

ONE EARTH FUTURE FOUNDATION

525 Zang Street

Broomfield, CO 80021 USA

Ph. +1.303.533.1715 Fax +1 303.309.0386 